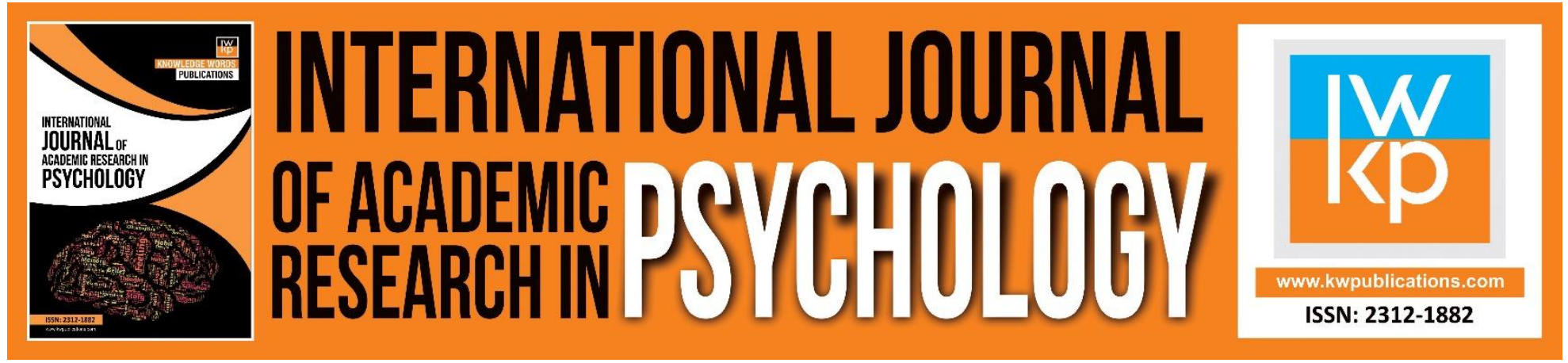

\title{
The Relationship between Mindfulness and Cognitive Emotion Regulation and Depression among University Students
}

\section{Majid Sadoughi, Fatemeh Hesampour}

To Link this Article: http://dx.doi.org/10.46886/IJARP/v3-i1/2378

DOI:10.46886/IJARP/v3-i1/2378

Received: 23 April 2016, Revised: 25 June 2016, Accepted: 06 July 2016

Published Online: 15 July 2016

In-Text Citation: (Sadoughi, \& Hesampour, 2016)

To Cite this Article: Sadoughi, M., \& Hesampour, F. (2016). The Relationship between Mindfulness and Cognitive Emotion Regulation and Depression among University Students. International Journal of Academic Research in Psychology. 3(1), 37-47.

\section{Copyright: (c) 2016 The Author(s)}

Published by Knowledge Words Publications (www.kwpublications.com)

This article is published under the Creative Commons Attribution (CC BY 4.0) license. Anyone may reproduce, distribute, translate and create derivative works of this article (for both commercial and non-commercial purposes), subject to full attribution to the original publication and authors. The full terms of this license may be seen at: http://creativecommons.org/licences/by/4.0/legalcode

Vol. 3, No. 1, 2016, Pg. 37 - 47

Full Terms \& Conditions of access and use can be found at https://kwpublications.com/pages/detail/publication-ethics 


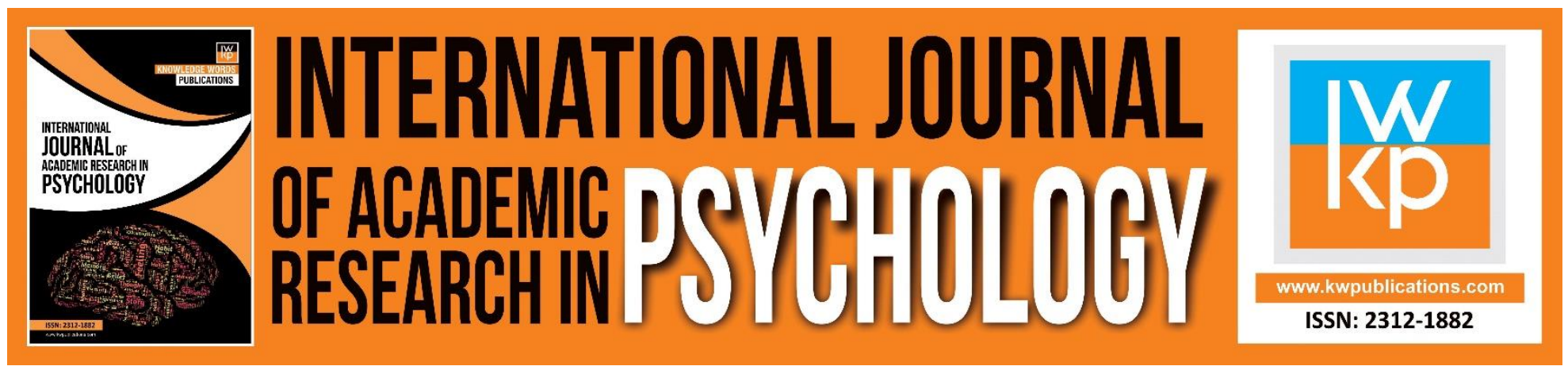

\title{
The Relationship between Mindfulness and Cognitive Emotion Regulation and Depression among University Students
}

\author{
Majid Sadoughi \\ Assistant Professor of Psychology, University of Kashan \\ Email: Sadoughi@kashanu.ac.ir \\ Fatemeh Hesampour \\ M. A. Student of Educational Psychology, University of Kashan \\ Email: Fatemeh.Hesampour@Yahoo.com
}

\begin{abstract}
Admission at university can be considered as a critical phase in life of young students, leading them to enter a greater society and experience a different educational, social, and cultural setting. Generally, these drastic changes in their personal and social lives would be accompanied by intense anxiety and stress, negatively influencing their performance and efficiency; as a result, their mental vulnerability would be intensified. Hence, the present study aimed to investigate the relationship between mindfulness and cognitive emotion regulation, in one hand, and depression, on the other hand. The target population included university students studying in 2015-2016 academic year in University of Kashan, Iran. Using Krejcie \& Morgan Table (1970), 355 university students were selected through stratified multi-stage sampling. The respondents completed Freiburg Mindfulness Inventory (2001), Cognitive Emotion Regulation Questionnaire (2001), and Beck Depression Inventory-II (1996). The data were analyzed using Pearson Correlation and MultipleRegression Analysis in SPSS 18 Software. The results revealed that cognitive emotion regulation components and mindfulness have a statistically significant relationship with depression. Moreover, catastrophizing and self-blame could directly and mindfulness and refocusing on planning indirectly predict depression significantly. The findings imply that university students would suffer less depression by enhancing mindfulness and cognitive emotion regulation.
\end{abstract}

Keywords: Mindfulness, Cognitive Emotion Regulation, Negative Emotions, Depression, Students.

\section{Introduction}

A large number of students move away from their families and stay in dormitories at some point over the course of their studies. Apart from loneliness, new environment, academic demands, peer group 
pressure, financial strains, and relationship with new friends are some of the common issues that turn out to be stressors for some students. The students who are unable to cope and lack social support may experience depression or anxiety (Verger et al., 2010; Bouteyre, Maurel, \& Bernaud, 2007; Dyson \& Renk, 2006).

. The growing number of students referring to university counselling centers indicates many of them suffer mental, social, and educational problems (Keshtiaray, 2005). Students with psychological disorders mostly experience common educational problems including inattentiveness, distraction, inappropriate behavior, lack of social skills, helplessness, impulsivity, and extreme anxiety (Isazaegan, Jenaabadi, \& Saadatmand, 2010). Furthermore, students' mental problems might negatively influence their academic performance, resulting in inefficient use of much of their abilities. For example, Price, McLeod, Gleich and Hand. (2006) showed that $19 \%$ of females and $13 \%$ of males experience emotional and psychological problems like depression and anxiety upon entering university. Unfamiliarity with academic and cultural settings, homesickness, lack of interest in one's academic major, and lack of adaptiveness with other people negatively influence students' academic achievement and cause mental problems like depression (Aghakhani \& Baghaei, 2000). Depression is characterized by lack of interest, guilty, inattentiveness, etc. which are accompanied by changes in different levels of activities, cognitive abilities, and sleep (Akiskal, 2001).

Students' emotional response and cognitive emotion regulation ability are important factors affecting general health and performance and considered as determining factors in their psychological well-being and efficient performance (Mashhadi, Doroghi, \& Hasani, 2011). In contrast, weak emotion regulation leads to mental disorders such as depression and anxiety (Isazadegan et al., 2010). Yousefi (2010) found that students' emotional response to stressful situations and the regulation strategies they employ are important factors in their academic performance and mental health. Garnefski, Kraaij, \& Spinhoven (2007) found that most people with depression apply negative cognitive emotion regulation strategies such as rumination and catastrophizing to deal with unpleasant circumstances. Hence, any failure in emotion regulation can cause vulnerability to psychological problems like depression and anxiety (Garnofky, 2003; Sayyah et al., 2014). Based on Gross Model (1999), emotion regulation includes all conscious and unconscious strategies applied to promote, maintain, and reduce cognitive, emotional, and behavioral aspects of an emotional response. Emotional responses provide valuable information about how individuals learn to behave in order to deal with emotions and behave with others based on their emotions (Esmaili et al., 2012). Emotions cannot be classified as either appropriate or inappropriate; however, it can be claimed that by regulating all emotions, they might be considered as helpful and appropriate; otherwise, they would be regarded as inappropriate and harmful (Gross, 1998). Kelly (1999) found that showing inefficient and inappropriate responses like distress and sadness and applying inadequate strategies lead to emotional distress and mental disorders like depression among students. Hence, cognitive emotion regulation could be considered as a fundamental principle in initiating, evaluating, and organizing adaptive behaviors as well as in preventing negative emotions (Mashhadi et al., 2011) and plays a significant role in developing depression symptoms after experiencing negative events (Garnefski et al., 2001). There is also a relationship between emotion regulation strategies and negative emotion reduction, emotions management, and well-being: less adaptive emotion regulation strategies like self-blame, catastrophizing, and rumination have a significant relationship with some negative emotions like stress, depression, and anxiety (Yousefi, 2006). 
Also, in line with metacognitive discussion about emotional disorders, Teasdale introduced a new therapeutic approach called Mindfulness-Based Cognitive Therapy. Metacognitive awareness refers to negative tendencies, thoughts, and emotions as well as stressful feelings, all of which are about temporal, cognitive events in contrast with real, concrete events. Mindfulness is defined as "the awareness that emerges through non-judgmental, purposeful attention in the present moment" (Kabat-Zinn, 2003). It is a skill helpful in perceiving stressful events less unfavorable than what they actually are. When individuals become aware of the present time, they do not pay attention to the past or future any longer. Most mental problems are generally related to events happening in the past or those which might happen in the future. For instance, depressed people mostly feel guilty and regret about the past and future, and the individuals with high anxiety show higher levels of stress and fear for future problems (Baer, 2003; Borkook, 2003; Kabat-Zinn, 2003; Robins, 2002). Mindfulness helps depressed individuals observe their thoughts and emotions non-judgmentally and consider their thoughts as passing events in the mind rather than inherent aspects of self or necessarily valid reflections of reality. This approach helps individuals with depression prevent intensification of their negative thoughts and emotions in rumination (Teasdale, Segal, \& Williams, 2000).

Considering previous research, it can be claimed that cognitive emotion regulation and mindfulness strategies seem important factors in developing depression. Higher mindfulness could help students know their abilities better, learn to encounter with negative emotions and thoughts, and experience their mental events positively (Bohlmeijer, Prenger, Taal, \& Cuijpers, 2010). Considering the increasing prevalence of depression among students (Kaviani, 2005), further research should address preventive which prevent depression. Given the impact of depression on education quality and students' life, the present study aims to investigate necessary strategies students need to apply to successfully regulate their negative, unpleasant thoughts and emotions. More specifically, the relationship between emotion regulation and mindfulness, in one hand, and depression, in the other, will be explored. Moreover, the present study will explore the extent to which cognitive emotion regulation strategies and mindfulness could predict depression among students.

\section{Method}

\section{Instruments}

\section{Cognitive Emotion Regulation Questionnaire (CERQ)}

Originally developed by Garnefski et al. (2001), CERQ was used to measure cognitive emotion regulation. This questionnaire consists of the following nine conceptually distinct subscales, each having four items and referring to what someone thinks after experiencing threatening or stressful events: Self-blame, referring to thoughts of putting the blame of what you have experienced on yourself; Other-blame, referring to thoughts of putting the blame of what you have experienced on the environment or another person; Rumination or focus on thought, referring to thinking about the feelings and thoughts associated with the negative event; Catastrophizing, referring to thoughts of explicitly emphasizing the terror of what you have experienced; Putting into Perspective, referring to thoughts of brushing aside the seriousness of the event/emphasizing the relativity when comparing it to other events; Positive Refocusing, referring to thinking about joyful and pleasant issues instead of thinking about the actual event; Positive Reappraisal, referring to thoughts of creating a positive meaning to the event in terms of personal growth; Acceptance, referring to thoughts of accepting what you have experienced and resigning yourself to what has happened; and Refocus on Planning, 
INTERNATIONAL JOURNAL OF ACADEMIC RESEARCH IN PSYCHOLOGY

Vol. 3, No. 1, 2016, E-ISSN: 2312-1882 @ 2016 KWP

referring to thinking about what steps to take and how to handle the negative event. For the purpose of the current study, a short 18-item version of the questionnaire in Persian (Hassani, 2011) was used. Items are rated based on a 5-point Likert scale ranging from 1 (never) to 5 (always). Cronbach's alpha for this version has been reported as 0.51-0.96 in previous studies (e.g., Hasani, 2010); furthermore, test-retest correlation coefficient has been found to be $0.51-0.71$, indicating a fair reliability (ibid). The correlation coefficient between different subscales of this inventory and those of Beck Depression Inventory shows good concurrent criterion-rated validity for CERQ. In the present study, the Cronbach's alpha was between 0.690 .78 .

\section{Freiburg Mindfulness Inventory (FMI)}

Mindfulness Inventory, originally designed by Buchheld, Grossman, \& Walach (2001), includes 30 four-point Likert items measuring non-judgmental present moment observation and openness to negative experiences. The short version of this inventory consisting of 14 items was used in the present study. The Cronbach's alpha coefficient of this version was calculated as 0.86 in the present study.

\section{Beck Depression Inventory}

To measure depression severity Beck Depression Inventory II (BDI-II; Beck, Steer, \& Brown, 1996), the most widely used instrument for detecting depression, was used. It consists of 21 self-report items rated 0-3. The total score of the inventory ranges from 0 to 63. Moreover, it has high internal consistency with Cronbach's alpha reliability of .91 (Beck et al., 1996; Beck, Steer, Ball, \& Ranieri, 1996). The Cronbach's alpha of this inventory was calculated as 0.86 in the present study.

\section{Results}

Descriptive statistics ( $M$ and SD), internal consistencies coefficients (Cronbach's $\alpha$ ), and bivariate inter-correlation coefficients (Pearson's $r$ ) for all measures are reported in Table. 
INTERNATIONAL JOURNAL OF ACADEMIC RESEARCH IN PSYCHOLOGY

Vol. 3, No. 1, 2016, E-ISSN: 2312-1882 @ 2016 KWP

Table 1. Descriptive indices and inter-correlations between research variables

\begin{tabular}{|c|c|c|c|c|c|c|c|c|c|c|c|c|c|}
\hline Variables & 1 & 2 & 3 & 4 & 5 & 6 & 7 & 8 & 9 & 10 & 11 & 12 & 13 \\
\hline $\begin{array}{l}1 . \\
\text { depression }\end{array}$ & 1 & & & & & & & & & & & & \\
\hline 2. & - & & & & & & & & & & & & \\
\hline mindfulnes & $.52^{*}$ & 1 & & & & & & & & & & & \\
\hline $\mathrm{S}$ & $*$ & & & & & & & & & & & & \\
\hline
\end{tabular}

$\begin{array}{llll}3 . & \text { self- } & .43^{*} & - \\ \text { blame } & & .27^{*} & 1\end{array}$

\begin{tabular}{|c|c|c|c|c|c|c|c|c|c|c|c|c|c|}
\hline $\begin{array}{l}4 . \\
\text { acceptance }\end{array}$ & $.35^{*}$ & $.38^{*}$ & $\begin{array}{l}- \\
.49^{*}\end{array}$ & 1 & & & & & & & & & \\
\hline $\begin{array}{l}\text { 5.ruminatio } \\
\mathrm{n}\end{array}$ & $.44^{*}$ & $.30^{*}$ & $.68^{*}$ & $\begin{array}{l}- \\
.44^{*}\end{array}$ & 1 & & & & & & & & \\
\hline $\begin{array}{l}\text { 6. positive } \\
\text { refocusing }\end{array}$ & $.23^{*}$ & $.38^{*}$ & $\begin{array}{l}- \\
.17^{*}\end{array}$ & $.26^{*}$ & $\begin{array}{l}- \\
.19^{*}\end{array}$ & 1 & & & & & & & \\
\hline $\begin{array}{l}\text { 7.refocuse } \\
\text { on planning }\end{array}$ & $\begin{array}{l}- \\
.52^{*} \\
*\end{array}$ & $.63^{*}$ & $.33^{*}$ & $.33^{*}$ & $\begin{array}{l}- \\
.29^{*}\end{array}$ & $\begin{array}{l}.41^{*} \\
*\end{array}$ & 1 & & & & & & \\
\hline $\begin{array}{l}\text { 8. positive } \\
\text { reappraisal }\end{array}$ & $.46^{*}$ & $.61^{*}$ & $\begin{array}{l}- \\
.30^{*}\end{array}$ & $.31^{*}$ & $.31^{*}$ & $.24^{*}$ & $\begin{array}{l}.37^{*} \\
*\end{array}$ & 1 & & & & & \\
\hline $\begin{array}{l}\text { 9.putting } \\
\text { into } \\
\text { Perspective }\end{array}$ & $\begin{array}{l}- \\
.20^{*}\end{array}$ & $.44^{*}$ & -.04 & .04 & -.03 & $.25^{*}$ & $\begin{array}{l}.46^{*} \\
*\end{array}$ & $\begin{array}{l}- \\
.53^{*}\end{array}$ & 1 & & & & \\
\hline $\begin{array}{l}10 . \\
\text { catastrophi } \\
\text { zing }\end{array}$ & $.59^{*}$ & $\begin{array}{l}- \\
.51^{*}\end{array}$ & $.63^{*}$ & $.51^{*}$ & $.71^{*}$ & $\begin{array}{l}- \\
.24^{*} \\
\end{array}$ & $\begin{array}{l}- \\
.55^{*} \\
\end{array}$ & $.42^{*}$ & $.12^{*}$ & 1 & & & \\
\hline $\begin{array}{l}\text { 11. other- } \\
\text { blame }\end{array}$ & $.25^{*}$ & $\begin{array}{l}- \\
.25^{*}\end{array}$ & $.34^{*}$ & $\begin{array}{l}- \\
.19^{*}\end{array}$ & $.37^{*}$ & $\begin{array}{l}- \\
.17^{*}\end{array}$ & $.25^{*}$ & $.21^{*}$ & -.08 & $.41^{*}$ & 1 & & \\
\hline $\begin{array}{l}\text { 12. negative } \\
\text { CER }\end{array}$ & $.55^{*}$ & $\begin{array}{l}- \\
.42^{*} \\
*\end{array}$ & $.85^{*}$ & $.53^{*}$ & $.88^{*}$ & $.24^{*}$ & $.45^{*}$ & $\begin{array}{l}- \\
.37^{*} \\
*\end{array}$ & -.08 & $.89^{*}$ & $.54^{*}$ & 1 & \\
\hline $\begin{array}{l}\text { 13. positive } \\
\text { CER }\end{array}$ & $.50^{*}$ & $.70^{*}$ & $.36^{*}$ & $.50^{*}$ & $.32^{*}$ & $.67^{*}$ & $.84^{*}$ & $.84^{*}$ & $.65^{*}$ & $\begin{array}{l}- \\
.51^{*}\end{array}$ & $\begin{array}{l}- \\
.36^{*}\end{array}$ & $\begin{array}{l}- \\
.46^{*}\end{array}$ & 1 \\
\hline Mean & $\begin{array}{l}16.9 \\
1\end{array}$ & $\begin{array}{l}34.7 \\
4\end{array}$ & $\begin{array}{l}12.6 \\
1\end{array}$ & $\begin{array}{l}12.4 \\
0\end{array}$ & $\begin{array}{l}13.7 \\
8\end{array}$ & $\begin{array}{l}11.5 \\
6\end{array}$ & $\begin{array}{l}12.7 \\
6\end{array}$ & $\begin{array}{l}12.7 \\
2\end{array}$ & $\begin{array}{l}12.0 \\
7\end{array}$ & $\begin{array}{l}11.3 \\
0\end{array}$ & $\begin{array}{l}12.9 \\
4\end{array}$ & $\begin{array}{l}50.6 \\
5\end{array}$ & $\begin{array}{l}60.2 \\
5\end{array}$ \\
\hline
\end{tabular}


INTERNATIONAL JOURNAL OF ACADEMIC RESEARCH IN PSYCHOLOGY

Vol. 3, No. 1, 2016, E-ISSN: 2312-1882 @ 2016 KWP

\begin{tabular}{llllllllllllll}
\hline $\begin{array}{l}\text { Standard } \\
\text { Deviation }\end{array}$ & $\begin{array}{l}11.6 \\
0\end{array}$ & 5.78 & 3.92 & 2.62 & 3.75 & 3.91 & 3.87 & 4.13 & 3.25 & 4.51 & 1.71 & $\begin{array}{l}11.6 \\
7\end{array}$ & 7.37 \\
\hline
\end{tabular}

${ }^{\star} \mathrm{P}<.05, \&{ }^{\star \star} \mathrm{P}<.01$

According to Table 1, positive cognitive regulation strategies including acceptance, positive refocusing, positive reappraisal, refocusing on planning and putting into perspective have inverse significant relationship with students' depression. On the other hand, negative cognitive emotion strategies including self-blame, rumination, catastrophizing, and other-blame have direct significant correlation coefficient with depression among students.

Stepwise multiple regression analysis was used to predict depression and determine the distinctive role of each cognitive emotion regulation component and mindfulness in explaining depression variance and detecting the best predictors.

The results of depression regression analysis based on cognitive emotion regulation and mindfulness showed that catastrophizing $\left(\Delta R^{2}=.35, F(1,353)=189.864, P=.001\right)$, mindfulness $\left(\Delta R^{2}=.069\right.$, $F(1,352)=41.781, P=.001)$, refocus on planning $\left(\Delta R^{2}=.015, F(1,351)=9.551, P=.002\right)$, and self-blame $\left(\Delta R^{2}=.015, F(1,350)=5.208, P=.023\right)$ could predict $44 \%$ of depression variance in four steps, respectively. Other components of emotion regulation did not enter the equation at step five of the analysis since they could not predict depression significantly. Table 2 demonstrates standardized and unstandardized regression coefficients in the fourth step.

Table 2. standardized and unstandardized coefficients of stepwise regression of depression based on cognitive emotion regulation and mindfulness

\begin{tabular}{|c|c|c|c|c|c|c|}
\hline \multirow{2}{*}{\multicolumn{2}{|c|}{ Model }} & \multicolumn{2}{|c|}{$\begin{array}{l}\text { Unstandardized } \\
\text { Coefficients }\end{array}$} & \multirow{3}{*}{$\begin{array}{l}\begin{array}{l}\text { Standardized } \\
\text { Coefficients }\end{array} \\
\text { Beta } \\
\end{array}$} & \multirow{3}{*}{$\begin{array}{l}t \\
-.218\end{array}$} & \multirow{3}{*}{$\begin{array}{r}\text { Sig } \\
.828\end{array}$} \\
\hline & & B & SE & & & \\
\hline \multirow{2}{*}{1} & (Constant) & -.293 & 1.344 & & & \\
\hline & Catastrophizing & 1.522 & .110 & .591 & 13.779 & .000 \\
\hline \multirow{3}{*}{2} & (Constant) & 25.581 & 4.200 & & 6.09 & .00 \\
\hline & Catastrophizing & 1.11 & .12 & .43 & 9.19 & .00 \\
\hline & Mindfulness & -.61 & .09 & -.30 & -6.46 & .00 \\
\hline \multirow{4}{*}{3} & (Constant) & 27.89 & 4.21 & & 6.61 & .00 \\
\hline & Catastrophizing & .98 & .12 & .38 & 7.69 & .00 \\
\hline & Mindfulness & -.44 & .10 & -.22 & -4.13 & .00 \\
\hline & $\begin{array}{ll}\begin{array}{l}\text { Refocuse } \\
\text { planing }\end{array} & \text { on } \\
\end{array}$ & -.51 & .16 & -.17 & -3.09 & .002 \\
\hline \multirow{5}{*}{4} & (Constant) & 26.40 & 4.24 & & 6.22 & .00 \\
\hline & Catastrophizing & .77 & .15 & .30 & 4.99 & .00 \\
\hline & Mindfulness & -.46 & .10 & -.23 & -4.32 & .00 \\
\hline & $\begin{array}{l}\text { Refocuse on } \\
\text { planing }\end{array}$ & -.51 & .16 & -.17 & -3.09 & .002 \\
\hline & Self-blame & .35 & .15 & .11 & 2.28 & .023 \\
\hline
\end{tabular}


INTERNATIONAL JOURNAL OF ACADEMIC RESEARCH IN PSYCHOLOGY

Vol. 3, No. 1, 2016, E-ISSN: 2312-1882 @ 2016 KWP

According to Table 2, depression could be predicted directly by catastrophizing in the first step, indirectly by mindfulness and refocus on planning in the second and third step, and directly by selfblame in the fourth step.

\section{Discussion}

The results of the study also indicated that there is a significant relationship between cognitive emotion regulation and depression, which is in agreement with Garnefski et al. $(2001 ; 2002)$ and Kraaij et al. (2003) who found that cognitive emotion regulation strategies play a significant role in the relationship between negative events and depression symptoms. Moreover, findings of various studies indicate that cognitive emotion regulation strategies such as self-blame, rumination, and catastrophizing are closely related with mental disorders like depression (Garfnefsky et al., 2001; 2002, Kraaij et al., 2003; Granefski \& Kraaij, 2006). Also, Mashhadi et al. (2011) showed that emotion regulation is considered as a key factor in adaptability with stressful life events, and there is a significant, positive relationship between depression and self-blame, blaming others, rumination, and catastrophizing strategies. The positive relationship between blaming others and depression is also in agreement with findings of Hassani (1389); Kraaij et al. (2008). The aforementioned studies generally refer to the fact that overuse of self-blame, blaming others, rumination, and catastrophizing strategies as maladaptive reactions are accompanied by higher intensification and continuation of depression. The negative relationship between depression, in one hand, and planning, positive refocusing, positive reappraisal strategies, on the other hand, has also been reported in several other studies. The relevant research suggests that in encountering with stressful events, the individuals who apply adaptive (planning, positive refocusing, positive reappraisal and putting into perspective) strategies experience less depression. In fact, the negative relationship between depression and adaptive strategies is due to the fact that by using these strategies, the person appraises negative events with a new approach and attends to positive aspects and potential benefits of the event in the long term. Thus, the person suffers less stress and accepts the event more easily. The negative relationship between the acceptance strategy and depression scores could be justified by considering the fact that by accepting stressful events, the person endeavors to compensate for them in order to enhance his present life situation, while aspiring for better future. In agreement with relevant literature in this area, the findings of the present study reveal that using more rumination and catastrophizing strategies as well as fewer acceptance and positive refocusing strategies would lead to higher scores in depression. It is noteworthy that the catastrophizing strategy, among other aforementioned strategies, can best predict depression scores (Garnefski et al., 2002, 2003; 2005, Martin \& Dahlen, 2005); Mashhadi et al. (2011) maintain that therapists and counsellors should pay special attention to maladaptive strategies like self-blame, rumination, and catastrophizing in their treatment plans for emotional disorders.

The results of data analysis revealed that there is a negative relationship between mindfulness and depression, which is in line with PaPageorgiou and Wells (2000); Evans et al. (2008); Kaviani, Hatami, and Shafieabadi (2010); and Azargoon (2009). This might be due to the fact that attention to and awareness of thoughts and emotions are considered positive aspects of mindfulness, resulting in adaptive behaviors and positive psychological states and promotion of personal and social activities (Chembers, 2009). The results also confirm the findings of Brown and Ryan (2003) in which they concluded that mindfulness can predict self-regulation behavior and positive emotional states. In other words, mindfulness enhances non-judgmental emotions and is effective in clear observation 
and acceptance of emotions and physical phenomena (Ogden, 2006). Therefore, it makes the individuals aware of their positive and negative feelings, helping them improve and moderate their emotional states and reduce their depression. Although the present study is based on correlation and cannot provide a cause-and-effect relationship, it could be suggested that interventional protocols and specialized workshops on mindfulness should be held to help learners develop awareness of their perception, thoughts, and feelings and finally reduce their negative emotions such as depression. Therefore, based on the findings of the present study and previous research, it can be concluded that cognitive emotion regulation and mindfulness could be regarded as key factors in regulating and reducing students' depression. Moreover, it can be concluded that emotion regulation processes enhance one's ability to act and enjoy life.

\section{References}

Akiskal, H. (2001). Mood disorder in: Kaplan HI. Sadok BJ. Comprehensive text book of psychiatry: from Williams \& Wilkins. Baltimore: USA, 1284-1298.

Azargoon, H., Kajbaf, M. B., Molavi, H., \& Abedi, M. R. (2009). The effect of mindfulness training on mental rumination and depression of the students of Isfahan University. Daneshvar Raftar, 16(34), 13-20. [Persian].

Beck, A. T., Steer, R. A., \& Brown, G. K. (1996). Manual for the Beck Depression Inventory II. San Antonio, TX: Psychological Corporation.

Beck, A. T., Steer, R. A., Ball, R., \& Ranieri, W. F. (1996). Comparison of Beck Depression Inventories IA and II in psychiatric out patients. Journal of Personality, 67, 588-597.

Bohlmeijer, E., Prenger, R., Taal, E., \& Cuijpers, P. (2010). The effects of mindfulness-based stress reduction therapy on mental health of adults with a chronic medical disease: a metaanalysis. Journal of psychosomatic research, 68(6), 539-544.

Bouteyre, E., Maurel, M., \& Bernaud, J. L. (2007). Daily hassles and depressive symptoms among first year psychology students in France: The role of coping and social support. Stress and Health, 23(2), 93-99.

Brown, K. W., \& Ryan, R. M. (2003), "The benefits of being present Mindfulness and its role in psychological wellbeing", Journal of personality and Social psychology, 84, 822- 848.

Buchheld, N., Grossman, P., \& Walach, H. (2001). Measuring mindfulness in insight meditation (Vipassana) and meditation-based psychotherapy: The development of the Freiburg Mindfulness Inventory (FMI). Journal for Meditation and Meditation Research, 1(1), 11-34.

Chambers, R., Gullone, E., \& Allen, N. B. (2009). Mindful emotion regulation: An integrative review. Clinical psychology review, 29(6), 560-572.

Chang, V. Y., Palesh, O., Caldwell, R., Glasgow, N., Abramson, M., Luskin., \& Koopman, C. (2004). The effects of a mindfulness-based stress reduction program on stress, mindfulness self-efficacy, and positive states of mind Stress and Health, 20(3), 141-147.

Diefendorff, J. M., Richard, E. M., \& Yang, J. (2008). Linking emotion regulation strategies to affective events and negative emotions at work.Journal of Vocational behavior, 73(3), 498-508.

Dyson, R., \& Renk, K. (2006). Freshmen adaptation to university life: Depressive symptoms, stress, and coping. Journal of clinical psychology,62(10), 1231-1244.

Evans, S., Ferrando, S., Findler, M., Stowell, C., Smart, C., \& Haglin, D. (2008). Mindfulness-based cognitive therapy for generalized anxiety disorder. Journal of anxiety disorders, 22(4), 716-721. 
INTERNATIONAL JOURNAL OF ACADEMIC RESEARCH IN PSYCHOLOGY

Vol. 3, No. 1, 2016, E-ISSN: 2312-1882 @ 2016 KWP

Esmaeili, L., Aghaei, A., Abedi, M. R., \& Esmaeili, M. (2011). Effectiveness of emotion regulation in the mental health of epileptic girls. Thought \& Behavior in Clinical Psychology, 5(20), 31-42. [Persian].

Fredrickson, B. L., \& Joiner, T. (2002). Positive emotions trigger upward spirals toward emotional wellbeing. Psychological science, 13(2), 172-175.

Garnefski, N., \& Kraaij, V. (2006). Cognitive emotion regulation questionnaire-development of a short 18-item version (CERQ-short). Personality and Individual Differences, 41(6), 1045-1053.

Garnefski, N., Kraaij, V., \& Spinhoven, P. (2001). Negative life events, cognitive emotion regulation and emotional problems. Personality and Individual differences, 30(8), 1311-1327.

Garnefski, N., Legerstee, J., Kraaij, V., Van den Kommer, T., \& Teerds, J. A. N. (2002). Cognitive coping strategies and symptoms of depression and anxiety: A comparison between adolescents and adults. Journal of adolescence, 25(6), 603-611.

Garnefski, N., Teerds, J., Kraaij, V., Legerstee, J., \& van den Kommer, T. (2004). Cognitive emotion regulation strategies and depressive symptoms: Differences between males and females. Personality and Individual Differences, 36(2), 267-276.

Gross, J. J. (1998). The emerging field of emotion regulation: an integrative review. Review of general psychology, 2(3), 271.

Gross, J. J. (1999). Emotion regulation: Past, present, future. Cognition \& Emotion, 13(5), 551-573.

Hasani, J. (2010). The psychometric properties of the cognitive emotion regulation questionnaire (CERQ). Journal of Clinical Psycology, 2(3), 73-84. [Persian].

Hasani, Jafar. (2011).The reliability and validity of the short form of the cognitive emotion regulation questionnaire. Journal of research in behavioral sciences. 4(20), 229-240.

Ildarabady, E., Firouz, K. M., Mazloum, R., \& Navidian, A. (2004). prevalence of depression among students of zabol medical school (2002). Shahrekord university of medical sciences journal, 6(2), 15-21.

Isazaegan, A., Jenaabadi, H., \& Saadatmand, S. (2010). The relationship between cognitive emotion regulation strategies, emotional creativity and academic performance with mental health in university students. Journal of educational psychology studies, 7(12), 71-92. [Persian].

Jongsma, Jr, A. E., Peterson, L. M., \& Bruce, T. J. (2014). The Complete Adult Psychotherapy Treatment Planner: Includes DSM-5 Updates (Vol. 296). John Wiley \& Sons.

Kabat-Zinn, J. (2003). Mindfulness-based interventions in context: past, present, and future. Clinical psychology: Science and practice, 10(2), 144-156.

Kaviani, H., Hatami, N., \& Shafieabadi, A. E. (2009). The impact of mindfulness-based cognitive therapy on the quality of life in non-clinically depressed people. Advances in Cognitive Science. [Persian].

Kelly, W. E., Kelly, K. E., Brown, F. C., \& Kelly, H. B. (1999). Gender differences in depression among college students: A multi-cultural perspective. College Student Journal, 33(1), 72-72.

Kraaij, V., Garnefski, N., \& Vlietstra, A. (2008). Cognitive coping and depressive symptoms in definitive infertility: a prospective study. Journal of Psychosomatic Obstetrics \& Gynecology, 29(1), 9-16.

Kraaij, V., Garnefski, N., de Wilde, E. J., Dijkstra, A., Gebhardt, W., Maes, S., \& Ter Doest, L. (2003). Negative life events and depressive symptoms in late adolescence: Bonding and cognitive coping as vulnerability factors?. Journal of youth and adolescence, 32(3), 185-193.

Krejcie, R. V., \& Morgan, D. W. (1970). Determining sample size for research activities. Educational and Psychological Measurement, 30, 607-610. 
INTERNATIONAL JOURNAL OF ACADEMIC RESEARCH IN PSYCHOLOGY

Vol. 3, No. 1, 2016, E-ISSN: 2312-1882 @ 2016 KWP

Keshtiaray N. (2005). The assessment of counseling and mental health centers' programs at Esfahan University of Medical Science [dissertation]. Esfahan.

Martin, R. C., \& Dahlen, E. R. (2005). Cognitive emotion regulation in the prediction of depression, anxiety, stress, and anger. Personality and Individual Differences, 39(7), 1249-1260.

Mashhadi, A., Doroghi, M. F., \& Hasani, J. (2011). The role of cognitive emotion regulation strategies in internalizing disorders of children. Journal of Clinical Psycology, 3(3), 29-39. [Persian].

Matsumoto, D., LeRoux, J. A., Iwamoto, M., Choi, J. W., Rogers, D., Tatani, H., \& Uchida, H. (2003). The robustness of the intercultural adjustment potential scale (ICAPS): the search for a universal psychological engine of adjustment. International Journal of Intercultural Relations, 27(5), 543562.

Minton, K., Ogden, P., \& Pain, C. (2006). Trauma and the Body: A Sensorimotor Approach to Psychotherapy (Norton Series on Interpersonal Neurobiology). WW Norton \& Company.

Nolen-Hoeksema, S., \& Davis, C. G. (1999). " Thanks for sharing that": ruminators and their social support networks. Journal of personality and social psychology, 77(4), 801.

Ogden, P., Minton, K., \& Pain, C. (2006). Trauma and the body: A sensorimotor appapproach to psychotherapy (norton series on interpersonal neurobiology). WW Norton \& Company.

Price, E. L., McLeod, P. J., Gleich, S. S., \& Hand, D. (2006). One-year prevalence rates of major depressive disorder in first-year university students. Canadian Journal of Counselling, 40(2), 68.

Sayah, M., Olapur, A., Ardame, A., Shahidi, S., \& Askarabad, Y. E. (2014). Prediction of mental health and academic performance of students within cognitive emotional regulation strategies in medical sciences university of jundishapur. Educational development of Jundishapur, 5(1), 37-44. [Persian].

Schulman, P., Roe, E., Eeten, M. V., \& Bruijne, M. D. (2004). High reliability and the management of critical infrastructures. Journal of Contingencies and Crisis Management, 12(1), 14-28.

Teasdale, J. D., \& Barnard, P. J. (1995). Affect, cognition, and change: Re-modelling depressive thought. Psychology Press.

Teasdale, J. D., Moore, R. G., Hayhurst, H., Pope, M., Williams, S., \& Segal, Z. V. (2002). Metacognitive awareness and prevention of relapse in depression: empirical evidence. Journal of consulting and clinical psychology, 70(2), 257.

Teasdale, J. D., Segal, Z. V., \& Williams, J. M. G. (2003). Mindfulness training and problem formulation. Clinical psychology: Science and practice, 10(2), 157-160.

Verger, P., Guagliardo, V., Gilbert, F., Rouillon, F., \& Kovess-Masfety, V. (2010). Psychiatric disorders in students in six French universities: 12-month prevalence, comorbidity, impairment and helpseeking. Social psychiatry and psychiatric epidemiology, 45(2), 189-199.

Wells A. (2000). Emotional disorders and metacognition: Innovative cognitive therapy. UK: Wiley.

Yaryari, F., Moradi, A., Yahyazadeh, S. (2007). The relationship between emotional intelligence and locus of control with psychological well-being among students of Mazandaran University. Psychological studies. 3(1), 21-39. [Persian]. 